\title{
In what extent anemia coexists with cognitive impairment in elderly: a cross-sectional study in Greece Stella Argyriadou ${ }^{1,2}$, Ioannis Vlachonikolis ${ }^{3}$, Haritini Melisopoulou ${ }^{1}$, Kostas Katachanakis3 and Christos Lionis ${ }^{* 2}$
}

Address: ${ }^{1}$ Health Centre of Chrisoupolis (HCC), Chrissoupolis 64 200, Macedonia, Greece, ${ }^{2}$ Clinic of Social and Family, School of Medicine, University of Crete, PO Box 1393, Heraklion, Crete, Greece and 3Laboratory of Biostatistics, School of Medicine, University of Crete, PO Box 1393, Heraklion, Crete, Greece

E-mail: Stella Argyriadou - starge@otenet.gr; Ioannis Vlachonikolis - l.Vlachonikolis@surrey.ac.uk; Haritini Melisopoulou - starge@otenet.gr; Kostas Katachanakis - drknk@ hotmail.com; Christos Lionis* - lionis@med.uoc.gr ${ }^{*}$ Corresponding author

This article is available from: http://www.biomedcentral.com/I47I-2296/2/5

(c) 200I Argyriadou et al; licensee BioMed Central Ltd. Verbatim copying and redistribution of this article are permitted in any medium for any noncommercial purpose, provided this notice is preserved along with the article's original URL. For commercial use, contact info@biomedcentral.com

\begin{abstract}
Background: A project aimed at studying the frequency of dementia and depression in the catchment area of the Health Centre of Chrissoupolis ( $\mathrm{HCCh}$ ), Northern Greece, was carried out. This paper reports the association between $A D$ and anemia among the elderly participants in this Greek study.
\end{abstract}

Methods: Eligible participants were people 65 years or over who were (a) living in the Elderly People's Home (all 48 subjects included); (b) visiting the Open Center for Elderly People during a 20 workday period (75 subjects) and (c) visiting the HCCh for routine medical care. The Mini Mental State Examination (MMSE) was used in assessing the cognitive capacity of the participants. Blood was drawn for serum hematocrit, vitamin $\mathrm{BI} 2$ and folate determination.

Results: The prevalence proportions of possible cognitive impairment among anemic and nonanemic males were $55.6 \%$ and $34.4 \%$, respectively $\left(X^{2}=5.8\right.$, d.f. $\left.=I, P=0.016\right)$. The corresponding proportions in females were $47.5 \%$ and $40.1 \%\left(X^{2}=1 . I\right.$, d.f. $\left.=1, p=0.305\right)$. Using logistic regression analysis, age-group ( $\geq 80 \mathrm{yrs}$ ), type of Institute, vitamin $B_{12}$ and anemia had significant independent associations with possible cognitive impairment.

Conclusions: Anemia is a frequent finding in elderly and it may be a risk factor for dementia, but the extent of the associated deterioration of cognitive impairment or the relation with $A D$ is not known. GPs should be aware of this coexistence and recommend for screening, assaying and treating elderly people.

\section{Background}

Alzheimer's disease (AD) and other neurodegenerative diseases affect large parts of the population worldwide and they constitute a serious public health problem for the aging European population [1-4]. General Practitioners seem to be able to diagnose early cognitive im- pairments, after training, among their elderly patients $[5,6]$. Identifying reversible and avoidable cognitive impairments seems to be also a challenge for future General Practitioners (GPs). There are many controversies regarding various associated factors, which can affect the incidence and progress of Alzheimer's disease (AD) $[7,8]$. 
Among these factors, vitamin B12 deficiency and folate status deterioration have been extensively discussed. Although some studies reported that anemia might be a risk factor for $\mathrm{AD}$ in the elderly [9-12] this subject is still debated in the literature.

A project with the aim of studying the frequency of dementia and depression among the elderly people in the catchment area of the Chrisoupolis Health Center (HCCh) in Northern Greece has been carried out during the past few years. A high prevalence of cognitive impairment has recently been reported in this area [13]. Thus, it was interesting to study and discuss the laboratory findings of the eligible subjects together with their mental status ability. This paper reports the association between cognitive impairment and anemia among the elderly participants in this Greek study.

\section{Patients and Methods \\ Setting}

This cross-sectional study was carried out at the catchment area of the (HCCh) in Northern Greece, which comprises 22,000 inhabitants.

\section{Participants}

Eligible participants were people 65 years or over who were (a) living in the Elderly People's Home (all 48 subjects included); (b) visiting the Open Center for Elderly People during a 20 workday period (75 subjects) and (c) visiting the $\mathrm{HCCh}$ for routine medical care. The latter group comprised of 413 subjects, which were randomly selected among the elderly people visiting one of the two outpatient clinics of the health center for the same period of time. Thus the total number of participants was 536, 245 males and 291 females. Baseline data of the studied population were presented in Table 1 .

The study has been approved by the Scientific and Ethical Committee of the General Hospital of Kavala, Greece.

\section{Tests}

The Greek validated version of Mini Mental State Examination test (MMSE) was used [14]. For diagnostic classification of cognitive and mood disorders the criteria of ICD-10 were applied [15]. Any subject with an MMSE score of 24 or less was included in the possible cognitive impairment group for analyses.

Blood (10 cc) was drawn for mean hematocrit (HCT), vitamin B12 (Vit.B12) and serum folate concentrations and was assayed in the lab of the HCCh. HCT was defined with microHt method. Normal values were considered when HCT was $\geq 38 \%$ for males and $\geq 36 \%$ for females. Vit.B12 was defined with the Elisa method in the micro Merieux analyzer. Normal values for Vit.B12 were considered those higher or equal to $145 \mathrm{pg} / \mathrm{mL}$. Folate was determined with ICIA method (Ion Capture Imune Assay), in Imx automatic analyzer. Normal values for folate were considered those higher or equal to $1.8 \mathrm{ng} / \mathrm{mL}$. Quality control is applied at this lab on a regular basis.

Table I: Demographic and backgrounds characteristics of the studied population

\begin{tabular}{|c|c|c|c|c|}
\hline Variable & Elderly & Open & Chrissoupolis & \\
\hline & People's & Centre for & Health & Total \\
\hline & Home & Elderly & Centre & \\
\hline & & People & & \\
\hline & N (\%) & $\mathrm{N}(\%)$ & $\mathrm{N}(\%)$ & $\mathrm{N}$ \\
\hline \multicolumn{5}{|l|}{ Age } \\
\hline $65-74$ years & - & $73(27.1)$ & $196(72.9)$ & 269 \\
\hline $75-84$ & $32(17.1)$ & $2(1.1)$ & $153(81.8)$ & 187 \\
\hline $85+$ & $16(20.0)$ & - & $64(80.0)$ & 80 \\
\hline Total & $48(9.0)$ & $75(14.0)$ & $413(77.1)$ & 536 \\
\hline \multicolumn{5}{|l|}{ Sex } \\
\hline Males & $19(7.75)$ & $72(29.4)$ & 154 (62.9) & 245 \\
\hline Females & $29(10.0)$ & $28(9.6)$ & $234(80.5)$ & 291 \\
\hline \multicolumn{5}{|l|}{ Marital status } \\
\hline Married & - & $71(18.0)$ & $324(82.0)$ & 395 \\
\hline Widowed & $48(34.04)$ & $4(2.8)$ & $89(63.1)$ & $14 \mid$ \\
\hline \multicolumn{5}{|l|}{ Education level } \\
\hline$<6$ years education & $17(13.4)$ & $9(7.1)$ & I0I (79.5) & 127 \\
\hline 6 years education & II (3.5) & $32(10.2)$ & $270(86.3)$ & 313 \\
\hline $6-12$ years education & $20(20.8)$ & $34(35.4)$ & $42(43.7)$ & 96 \\
\hline
\end{tabular}


Table 2: HCT, Vit.B 12 and Folate and cognitive capacity (number of people and prevalence proportions)

\begin{tabular}{|c|c|c|c|}
\hline & $\begin{array}{r}\text { MMSE > } 24 \\
N(\%)\end{array}$ & $\begin{array}{r}\text { MMSE } \leq 24 \\
N(\%)\end{array}$ & $\begin{array}{l}\text { Total } \\
N(\%)\end{array}$ \\
\hline \multicolumn{4}{|l|}{ HCT } \\
\hline \multicolumn{4}{|l|}{ Normal* } \\
\hline Male & $137(65.6)$ & $72(34.4)$ & $209(100)$ \\
\hline Female & 139 (59.9) & $93(40.1)$ & $232(100)$ \\
\hline Total & $276(62.6)$ & $165(37.4)$ & $441(100)$ \\
\hline \multicolumn{4}{|l|}{ Abnormal } \\
\hline Male & $16(44.4)$ & $20(55.6)$ & $36(100)$ \\
\hline Female & $31(52.5)$ & $28(47.5)$ & $59(100)$ \\
\hline Total & 47 (49.5) & $48(50.5)$ & $95(100)$ \\
\hline \multicolumn{4}{|l|}{ Vit.B I 2} \\
\hline \multicolumn{4}{|l|}{ Normal } \\
\hline Male & $144(65.2)$ & 77 (34.8) & $221(100)$ \\
\hline Female & 154 (59.5) & $105(40.5)$ & $259(100)$ \\
\hline Total & $298(62.1)$ & $182(37.9)$ & $480(100)$ \\
\hline \multicolumn{4}{|l|}{ Abnormal } \\
\hline Male & $9(37.5)$ & $15(62.5)$ & $24(100)$ \\
\hline Female & $16(50)$ & $16(50)$ & $32(100)$ \\
\hline Total & $25(44.6)$ & $31(55.4)$ & $56(100)$ \\
\hline \multicolumn{4}{|l|}{ Folate } \\
\hline \multicolumn{4}{|l|}{ Normal } \\
\hline Male & $149(62.3)$ & $90(37.7)$ & $239(100)$ \\
\hline Female & $166(58.9)$ & $116(4 I .1)$ & $282(100)$ \\
\hline Total & $315(60.3)$ & $206(39.5)$ & $521(100)$ \\
\hline \multicolumn{4}{|l|}{ Abnormal } \\
\hline Male & $4(66.7)$ & $2(33.3)$ & $6(100)$ \\
\hline Female & $4(44.4)$ & $5(55.6)$ & $9(100)$ \\
\hline Total & $8(53.3)$ & 7 (46.7) & $15(100)$ \\
\hline
\end{tabular}

* Normal value of HCT $\geq 38 \%$ in male and $>36$ in females

\section{Statistical analysis}

All statistical analyses were carried out using SPSS for Windows (Release 10.0). The associations between categorical variables, such as different subject groups and prevalence of disorders, were tested by means of Pearson's chi square-test or Fisher's test where was appropriate. To show the strength of the association, $p$-values are shown in the text [16]. Comparisons of mean values between groups were made by Student's t-test or analysis of variance. The independent influence of all potential factors in identifying the presence of cognitive impairment was studied by means of unconditional logistic regression analysis [17].

\section{Results}

Anemia and cognitive impairment

Ninety-five $(17.7 \%)$ out of the 536 participants were found to be anemic. Of those, 47 scored higher than 24 in the MMSE and 48 lower or equal to 24 (possibly cognitive impairment) (Table 2). The association between anemia and possible cognitive impairment was statistically significant $\left(X^{2}=5.6\right.$, d.f. $\left.=1, p=0.018\right)$. A separate analysis by gender revealed that this association was true only for males and not for females. In fact, in males the prevalence proportions of possible cognitive impairment among anemic and non-anemic subjects were $55.6 \%$ and $34.4 \%$, respectively $\left(\mathrm{X}^{2}=5.8\right.$, d.f. $\left.=1, \mathrm{p}=0.016\right)$. The corresponding proportions in females were $47.5 \%$ and $40.1 \%\left(X^{2}=1.1\right.$, d.f. $\left.=1, p=0.305\right)$.

\section{Vitamin B 2 and cognitive impairment}

The analysis of blood sample of the participants indicated an abnormal value of Vit.B12 in 56 (10.4\%) subjects. Of those, 25 subjects scored as normal in the cognitive test and 31 were assessed as possibly cognitive impaired. The prevalence proportions of possible cognitive impairment among male participants with normal and abnormal value of Vit.B12 were significantly different, $34.8 \%$ and $62.5 \%$, respectively $\left(\mathrm{X}^{2}=7.1\right.$, d.f. $\left.=1, \mathrm{p}=0.008\right)$. The corresponding proportions in females were not significantly different, $40.5 \%$ and $50.0 \%\left(\mathrm{X}^{2} 1.0\right.$, d.f. $=1, \mathrm{p}=$ o.306).

\section{Folate and cognitive impairment}

Fifteen $(2.7 \%$ ) subjects ( 7 with a MMSE lower or equal to 24) were found to have an abnormal value of folic acid. The prevalence proportions of possible cognitive impairment among participants with normal or abnormal value of folic acid were $39.5 \%$ and $46.7 \%$, respectively. The association between folic acid and possible cognitive impairment was not significant $\left(\mathrm{X}^{2}=0.3\right.$, d.f. $=1, \mathrm{p}=$ o.578).

\section{Differences among the three institutions}

A two-way analysis of variance, by MMSE classification and institution, revealed significant differences between the three institutions in HCT and folate $(\mathrm{F}=4.2$, d.f. $=2$ and 530, $\mathrm{p}=0.016$ and $\mathrm{F}=4.9$, d.f. $=2$ and 530, $\mathrm{p}=$ 0.008 , respectively), and marked, but not significant differences in Vit. $B_{12}(F=2.7$, d.f. $=2$ and 530, $p=0.068)$. The results depicted in Table 3 , show that subjects living in the Old People's Home (OPH), had the lowest value of HCT and Vit. $B_{12}$, while those participating in the Open Centre for the Elderly people (OCE) had the lowest value in folate. There were similar results with respect to differences between the two MMSE categories: participants with possible cognitive impairment had lower values in $\mathrm{HCT}$, Vit. $\mathrm{B}_{12}$ and folate, than those with normal MMSE score. The results in Table 3, show that the above results for the MMSE categories were not consistent across all three institutions, in particular those for Vit. $B_{12}$ and folate, where a reverse difference was observed in subjects from the OPH. This MMSE classification by institution interaction was significant only for folate $(F=9.1$, d.f. $=2$ and 530, $\mathrm{p}<0.001$ ). 
Table 3: Mean values (and standard deviations) of $\mathrm{HCT}, \mathrm{Vit}_{\mathrm{B}} \mathrm{B}_{12}$ and Folate in different places

\begin{tabular}{|c|c|c|c|c|}
\hline Variable & $\begin{array}{l}\text { HCCh } \\
\text { M.A.(SD) }\end{array}$ & $\begin{array}{l}\text { OCE } \\
\text { M.A.(SD) }\end{array}$ & $\begin{array}{l}\text { OPH } \\
\text { M.A.(SD) }\end{array}$ & $\begin{array}{l}\text { Total } \\
\text { M.A.(SD) }\end{array}$ \\
\hline \multicolumn{5}{|l|}{ Hct (\%) } \\
\hline MMSE > 24 & $40.1(3.3)$ & 40.1 (3.6) & $39.5(3.7)$ & $40.1(3.3)$ \\
\hline MMSE $\leq 24$ & $39.6(4.7)$ & $36.5(6.9)$ & $37.9(4.3)$ & $39.1(4.8)$ \\
\hline Total & $39.9(3.8)$ & $39.5(4.5)$ & $38.2(4.2)$ & $39.7(4)$ \\
\hline \multicolumn{5}{|c|}{ Vit. $_{12}(\mathrm{pg} / \mathrm{mL})$} \\
\hline MMSE > 24 & $463.5(197.6)$ & $465.0(261.9)$ & $377.2(207.6)$ & $460.9(211.6)$ \\
\hline MMSE $\leq 24$ & $438.3(203.7)$ & $330.9(242.2)$ & 434.3 (294.9) & 431.1 (224.6) \\
\hline Total & $453.6(200.2)$ & $441.7(262.1)$ & $421.2(276.3)$ & $449(217.1)$ \\
\hline \multicolumn{5}{|l|}{ Folate $(\mathrm{ng} / \mathrm{mL})$} \\
\hline MMSE > 24 & $9.3(3.3)$ & $11.3(5.6)$ & $8.5(7.8)$ & $9.6(4.1)$ \\
\hline MMSE $\leq 24$ & $8.0(3.7)$ & $7.9(5.9)$ & 13.4(8.5) & $8.9(5.4)$ \\
\hline Total & $8.8(3.5)$ & $10.7(5.8)$ & $12.3(8.5)$ & $9.4(4.7)$ \\
\hline
\end{tabular}

Table 4: Results of the unconditional regression analysis

\begin{tabular}{|c|c|c|c|c|c|}
\hline Variable & B & SE & P-value & Odds ratio & $95 \% \mathrm{Cl}$ \\
\hline \multicolumn{6}{|l|}{$A g e^{a}$} \\
\hline Ageb & 0.360 & 0.250 & 0.150 & $\mathrm{I} .4$ & $0.9-2.3$ \\
\hline Agec & 1.123 & 0.256 & 0.001 & 3.1 & $1.9-5.1$ \\
\hline \multicolumn{6}{|l|}{ Place } \\
\hline \multicolumn{6}{|l|}{ Group } \\
\hline Groupd & -0.854 & 0.349 & 0.014 & 0.4 & $0.2-0.8$ \\
\hline Group ${ }^{f}$ & 1.513 & 0.407 & 0.001 & 4.5 & $2.0-10.1$ \\
\hline $\mathrm{B} \mid 2^{\mathrm{g}}$ & 0.714 & 0.338 & 0.034 & 2.0 & I.I-4.0 \\
\hline Anemiag & 0.535 & 0.262 & 0.041 & 1.7 & $1.02-2.9$ \\
\hline Folateg & 1.323 & 0.714 & 0.064 & 3.8 & $0.9-15.2$ \\
\hline
\end{tabular}

a: 64-70 yrs b: 7I-79 c: $\geq 80$ d: Health Centre e: Open Centre for Elderly f: Old Peoples Home g: Abnormal value

\section{Logistic regression analysis}

The results of the logistic regression analysis (backward, unconditional maximum likelihood) are illustrated in Table 4. Age-group ( $\geq 80$ yrs), type of institution, anemia, Vit. $B_{12}$ and folate concentrations had marked or significant independent influences on the presence of cognitive impairment, as indicated by MMSE score less than the cutoff point of $\leq 24$. Table 4 , shows also the odds - ratios and 95\% $\mathrm{Cl}$ for each of the above factors; it can be seen that the risk of cognitive impairment (as measured by the odds-ratio) for age greater than 80 years, $\mathrm{OPH}$ residence and abnormal value of $\mathrm{HCT}$, Vit. $\mathrm{B}_{12}$ is significantly higher than one.

\section{Discussion}

It is widely accepted that anemia is a common health problem among elderly people, and cobalamin deficiency increases with advancing age. Although there are several studies which report an association between cobalamin deficiency and cognitive impairment [18-21], more studies are required to determine whether there is a specific profile of cognitive impairments typical of Vit.B12 deficiency. It is also widely accepted that cobalamin deficiency may result in a variety of atypical symptoms and hematological changes typical of megaloblastic anemia are frequently absent in the majority of patients with mental disorders [22].

Our study indicated an association between cognitive impairment and anemia, but causation cannot be as- 
sessed on the basis of the results of this cross-sectional study. Why this association exists needs further discussion. The impact which the changes on olfactory function and taste associated with AD may have on dietary intake, nutritional status and the haematinic factors is not examined in this study. The possible contribution of the concomitant diseases on the causation of anemia should not be ignored, when the results are interpreted. The present study is based on people who have visited the Health Centre and other older people who live at the community setting. This situation reflects the current figure of the real context in which the GPs are invited to work. Anemia was also based on the HCT findings, but both $\mathrm{HCT}$ and the blood $\mathrm{Hb}$ concentration remain the best available indirect indicators [23,24]. The validity and reliability of the used laboratory methods is an important issue as it can affect the study results. However the lab of the HCCh was using quality controls and all the blood tests were administered by the same assistant. The use of MMSE as a screening tool has also been discussed widely in the literature $[25,26]$. Even the MMSE's specificity and sensitivity can be affected by factors such as sex, education level, age [27] this tool remains to be a simple screening tool at GP's disposal for cognitive impairment and cannot be used to make even tentative psychiatric diagnoses [26,27].

Despite these limitations, our study adds to the existing literature. This study also reveals that people, who are living in Old People's Homes, were recognized at a specific risk and it is also in accordance with other reports $[28,29]$. The greater risk of male subjects having cognitive impairment when they are anemic in comparison with females has been reported in another study [9].

This Greek study may have some serious implications on the GPs attitude and practices when they identify elderly cognitive impaired subjects; specifically, they could recommend them a hematological investigation including HCT, CBC, Vit. $B_{12}$ and folic acid levels. The initiation of a adequate treatment with Vit.B12 and/or folate when laboratory indications exist, seems to be an effective strategy in General Practice and this treatment is recommended, even in cases with a normal score with MMSE. Some authorities recommend that serum $\mathrm{B}_{12}$ screening should be initially performed to all elderly patients, with further testing in those with a Vit. $\mathrm{B}_{12}$ level of less than $350 \mathrm{pg} / \mathrm{mL}$ (260 pmol / L) [20]. Seeking the effectiveness of different screening strategies, clinicians need to use their own judgment to decide how to identify Vit. $B_{12}$ deficiency before it leads to anemia or neurologic disease.

\section{Conclusions}

Anemia seems to be a risk factor for cognitive impairment. There are also many questions whether Vit. $B_{12}$ and folate deficiency work as risk factors on the onset of dementia and whether the appearance of dementia can be avoided by a supplemented treatment. Until definitive clarifying of those questions GPs should be warranted to screening, assaying, and treating elderly people.

\section{Competing interests}

None declared

\section{References}

I. Jorm AF, Korten AE, Henderson AS: The prevalence of dementia: a quantitative integration of the literature. Application of a new method for making projections. Ada Psychiatr Scand 1987, 78:493-500

2. Olafsdottir M, Marcusson J, Skoog I: Mental disorders among elderly people in primary care: The Linkoping study. Ada Psychiatr Scand 2001, 1 04:12-18

3. Kalaria RN, Ballard C: Stroke and cognition. Curr Atherosder Rep 200I, 3:334-339

4. Honig LS, Mayeux R: Natural history of Alzheimer's disease. Aging 2001, 13:171-182

5. Mant A, Eyland EA, Pond DC, Saunders NA, Chancellor AH: Recognition of dementia in general practice: comparison of general practitioners' opinions with assessments using the minimental state examination and the Blessed dementia rating scale. Fam Pract 1998, 5:184-188

6. Lionis C, Tzagournissakis M, latraki E, Kozyraki M, Antonakis N, Plaitakis A: Are Primary Care Physicians Able to Assess Dementia? An estimation of their capacity after a short-term training program in rural Crete. Am J Geriatr Psychiatry 200I, 9:315

7. Fylkesnes SI, Nygaard HA: Dementia and hypothyroidism. Tidsskr Nor Laegeforen 2000, I 20:905-907

8. Burke D, Sengoz A, Schwartz R: Potentially reversible cognitive impairment in patients presenting to a memory disorders clinic. J Clin Neurosci 2000, 7:120-123

9. Beard CM, Kokmen E, O'Brien PC, Ania BJ, Melton LJ 3th: Risk of Alzheimer's disease among elderly patients with anemia: population - based investigations in Olmsted Country, Minnesota. Ann Epidemiol 1997, 7:219-224

10. Rabins P: Pernicious anemia and reversible dementia: Strachan and Henderson 30 years later. Int J Geriatr Psychiatry 1998, I3:139-140

II. Jacques PF, Selhub J, Bostom AG, Wilson PW, Rosenberg IH: The effect of folic acid fortification on plasma folate and total homocysteine concentrations. N Engl J Med 1999, 340:|449-I454

12. Healton EB, Savage DG, Brust JC, Garrett TJ, Linenbaum J: Neurologic aspects of cobalamin deficiency. Medicine 1991, 70:229245

13. Argyriadou S, Melissopoulou H, Krania E, Karagiannidou A, Vlachonicolis J, Lionis C: Dementia and depression: two frequent disorders of the aged in primary health care in Greece. Fam Practice 200।, | 8:87-9|

14. Fountoulakis C, Tsolaki M, Chazi H, Kazis, Mini Mental State Examination (MMSE): A validation study in demented patients from the elderly Greek population. Encephalos (abstract in English) 1994, 3 I:93-102

15. World Health Organization: The ICD-I 0 classification of mental and behavioral disorders: clinical descriptions and diagnosing guidelines. Translated in Greek by Stefanis K, Soldatos K, Mavreas V (BETA Publications) Athens 1993

16. Armitage P, Berry G: Statistical Methods in Medical Research. 2nd ed. Oxford: Blackwell Scientific Publications 1987

17. Collett D: Modeling Binary Data. London: Chapman 8 Hall 1991

18. Milward EA, Grayson DA, Creasey H, Janu MR, Brooks WS, Broe GA: Evidence for association of anemia with vascular dementia. Neuroreport 1999, 10:2377-2381 
19. Carmel R, Gott PS, Waters CH, Cairo K, Green R, Bondareff W, et al: The frequently low cobalamin levels in dementia usually signify treatable metabolic, neurologic and eletrophysiologic abnormalities. Eur J Haematol 1995, 54:245-253

20. Douglas LS: Anemia in the elderly. Am Fam Physician 2000, 62:1565-1572

21. Bopp-Kistler I, Ruegger-Frey B, Grob D, Six P: Vitamin B I2 deficiency in geriatrics. Schwetz Med Prax 1999, 88:1867-1875

22. Larner AJ, Janssen JC, Cipolotti L, Rossor MN: Cognitive profile in dementia associated with vitamin $B \mid 2$ deficiency due to pernicious anemia. J Neurol 1999, 246:317-319

23. Walsh JR: Hematologic problems. In; Geriatric Medicine (Edited by Cassel CK, et al). New York. N.Y.: Springer 1997627-636

24. Mock DM, Bell EF, Lankford GL, Widness JA: Hematocrit correlates well with circulating red blood cell volume in very low birth weight infants. Pediatr Res 200I, 50:525-53I

25. Weissgarten J, Modai D, Oz D, Chen Levy Z, Cohn M, Marcus O, et al: Vitamin B (6) therapy does not improve hematocrit in hemodialysis patients supplemented with iron and erythropoietin. Nephron 2001, 87:328-332

26. Wind AW, Schellevis FG, Van Staveren G, Scholten RP, Jonker C, et al: Limitations of the Mini - Mental State Examination in diagnosing dementia in general practice. Int J Geriatr Psychiatry 1997, I 2:101-108

27. O'Connor DW, Pollitt PA, Hyde JB, Fellows JL, Miller ND, et al: The reliability and validity of the Mini-Mental State in a British community survey. J Psychiatr Res 1989, 23:87-96

28. O'Connor DW, Pollitt PA, Treasure FP, Brook CPB, Reiss BB: The influence of education, social class and sex on Mini-Mental State scores. Psychol 1989, 19:771-776

29. Essama-Tatjani JC, Guilland JC, Potier de Courcy G, Fuchs F, Richard $D$ : Folate status worsens in recently institutionalized elderly people without evidence of functional deterioration. I Am Coll Nutr 2000, 19:392-404

30. Weyerer S, Mann AH, Ames D: Prevalence of depression and dementia in residents of old age homes in Mannheim and Camden. Z Gerontol Geriatr 1995, 28:169-178

Publish with BioMed Central and every scientist can read your work free of charge

"BioMedcentral will be the most significant development for disseminating the results of biomedical research in our lifetime." Paul Nurse, Director-General, Imperial Cancer Research Fund

Publish with BMC and your research papers will be:

- available free of charge to the entire biomedical community

- peer reviewed and published immediately upon acceptance

- cited in PubMed and archived on PubMed Central

- yours - you keep the copyright

Submit your manuscript here:

http://www.biomedcentral.com/manuscript/
BioMedcentral.com editorial@biomedcentral.com 